\title{
Integration of Agriculture and Wildlife Ecosystem Services: A Case Study of Westham Island, British Columbia, Canada
}

\author{
Yuan Zhang, Julie E. Wilson, Les M. Lavkulich* \\ Master of Land and Water Systems, Faculty of Land and Food Systems, The University of British Columbia, Vancouver, Canada \\ Email: *lml@mail.ubc.ca
}

How to cite this paper: Zhang, Y., Wilson, J.E. and Lavkulich, L.M. (2017) Integration of Agriculture and Wildlife Ecosystem Services: A Case Study of Westham Island, British Columbia, Canada. Agricultural Sciences, 8, 409-425.

https://doi.org/10.4236/as.2017.85031

Received: April 21, 2017

Accepted: May 24, 2017

Published: May 27, 2017

Copyright ( 92017 by authors and Scientific Research Publishing Inc. This work is licensed under the Creative Commons Attribution International License (CC BY 4.0).

http://creativecommons.org/licenses/by/4.0/

\begin{abstract}
There is concern regarding the loss of ecosystem goods and services as a result of land use changes such as the expansion and intensification of agricultural activities. Assessments of these interactions require innovative analyses that combine qualitative and quantitative economic analyses. The Millennium Ecosystem Assessment framework was applied to a peri-urban region in British Columbia, Canada to assess the effects of the integration of agricultural programs and the maintenance of waterfowl habitat located on the Pacific Flyway. The Delta Farmland \& Wildlife Trust, a non-governmental organization, has implemented several activities to enhance ecosystem goods and services by cooperative programs among the agricultural community and wildlife interests. The successful collaborative framework has resulted in enhanced soil quality, increased biodiversity, and the maintenance of valuable agriculture and waterfowl habitat.
\end{abstract}

\section{Keywords}

Ecosystem Services, Agriculture, Land Use Change, Wildlife Habitat

\section{Introduction}

Increased agricultural production has contributed to global and local land use changes [1], often with ecosystem degradation and loss of ecosystem services [2] [3] [4] [5] [6]. A prime example is the relationship between loss of wildlife habitat and agriculture. Agricultural landscapes are dynamic and changes of land cover often occur rapidly and can result in conflict between agricultural production and wildlife habitat, especially in the short term. Interactions between agricultural crops and wildlife species and changes in agricultural landscapes can result in large effects on wildlife habitat as well as the structure of wildlife com- 
munities and biodiversity [7].

Because areas experiencing gains and losses are spatially unique, proportional constancy of a particular land cover type (habitat) at broader spatial scales (nationally) may not capture the impact of habitat change on wildlife at finer scales (regionally or locally). Thus, local changes in land use and their impacts on the ecosystem cannot be analyzed independently. To assess the ecological effects on the outcome of changes in land use, a framework of ecosystem goods and services is needed to provide a relative comparison that integrates both tangible (economic and quantitative) values and intangible (social, ecological, and qualitative) values [8].

Some ecological benefits are recognized by traditional economic analysis, for example crop or livestock production, while others, such as wildlife habitat or water quality are not. Reference [9] presents a framework of the effects of farming and land management on the services and disservices of ecological systems. He suggests integrating market and non-market valuation approaches. For example, some ecosystem services may be estimated by accounting for the market value of a product if removed (replacement value) and non-market values may be estimated by use of "revealed preference", or consumer choices among alternatives, and "stated preference", such as "willingness-to-pay". A regional study [10] integrated the two economic approaches to provide an overview of the value of natural capital in Canada and at a smaller scale, a "willingness-to-pay" study of the total public benefits provided by agricultural land, including the amenities and market benefits that farmland provides. Reference [10] contributed to the implementation of the public policy of natural capital in British Columbia, Canada [11].

The Lower Fraser Valley of British Columbia, Canada, is an example of the phenomena of landscape dynamics. This region is important for agricultural production, while also subject to development pressures, including various industries, urban residential expansion, transportation arteries (road and rail) connecting to port facilities, and tourism and recreation activities. In recognition of these pressures, the provincial government introduced regulations under the Agricultural Land Commission Act to restrict non-agricultural uses on the most productive soils within the province [12]. The challenge in implementation is to develop an optimal evaluation framework to manage these lands to sustain and enhance the viability of agriculture, and to better assess the provision of ecological services.

Within the Lower Fraser Valley, the municipality of Delta is located on the Pacific Flyway, an internationally significant migratory route and nesting area for migratory waterfowl [13]. In the municipality, the Delta Farmland and Wildlife Trust (DF\&WT), a non-profit organization, serves as a successful collaboration framework organization among wildlife and farming groups. The DF\&WT recognizes the significance of ecosystem services and the importance of the integration of agricultural production and the provision of habitat for breeding and feeding migratory waterfowl [14]. The mandate of the DF\&WT is to promote the preservation of farmland and associated wildlife habitat within the Fraser 
River delta, through sustainable farming and land stewardship [15]. Through the land stewardship programs offered to local farmers, DF\&WT enhances on-farm habitat for wildlife, while conserving soil resources. The organization also addresses and mitigates the perceived conflict between agricultural production and waterfowl habitat. The Delta location provides an ideal case study to address issues related to the integration of ecological goods and services within an agricultural landscape.

Westham Island, in the Municipality of Delta, has a long and documented history of agriculture that has had an important role in providing value to the agricultural community as well as wildlife (i.e. waterfowl) habitat. According to the Agricultural Land Use Inventory provided by the province of BC, about $95 \%$ of the land on Westham Island is within the provincially-regulated Agricultural Land Reserve [16].

As agricultural land on Westham Island is a significant source of ecosystem goods and services [13], several questions arise: do changes in production and land base affect other ecological services, and do these ecosystem services support sustained agricultural activity in the long term?

This study assesses the interaction of agricultural production and the provision of ecosystem goods and services on Westham Island, in Delta, BC. The assessment focuses on the contributions that intangible values (e.g., wildlife habitat, pollination, etc.) provide, both spatially and temporally, through management of the lands; it also evaluates the effects of programs initiated by DF\&WT, and discusses the importance of balancing agricultural and environmental land uses in the context of the published literature.

\section{Methods}

\subsection{Study Area}

Westham Island $\left(49^{\circ} 05^{\prime} 15^{\prime \prime} \mathrm{N}, 123^{\circ} 09^{\prime} 29^{\prime \prime} \mathrm{W}\right)$ is located within the municipality of Delta, a suburb of Vancouver, in southwestern British Columbia. This small island is in a productive agricultural region in the province (Figure 1). The region has a humid maritime climate with a mean annual temperature of $9.6^{\circ} \mathrm{C}$ and a mean annual precipitation of $1008 \mathrm{~mm}$ [17]. It is approximately 17 square kilometers of level lowland bordered by the Fraser River estuary, and the Strait of Georgia. The George C. Reifel Bird Sanctuary and Alaksen National Wildlife Area occupy the northern part of the island, which are identified as key habitats and stopover for waterfowl to nest, breed and feed on the Pacific Flyway (Figure 2) [13].

References [18] and [19] have published guidelines for the assessment of ecosystem goods and services. Reference [19] developed a five-category scheme of potential indicators of ecosystem services, consisting of: provisioning, regulating, supporting and contributing to amenity and cultural attributes. From these categories, the following indicators were selected that are relevant to the agricultural practices of the case study on Westham Island: food production, wildlife habitat, and ancillary ecosystem services including pollination, soil quality, and 


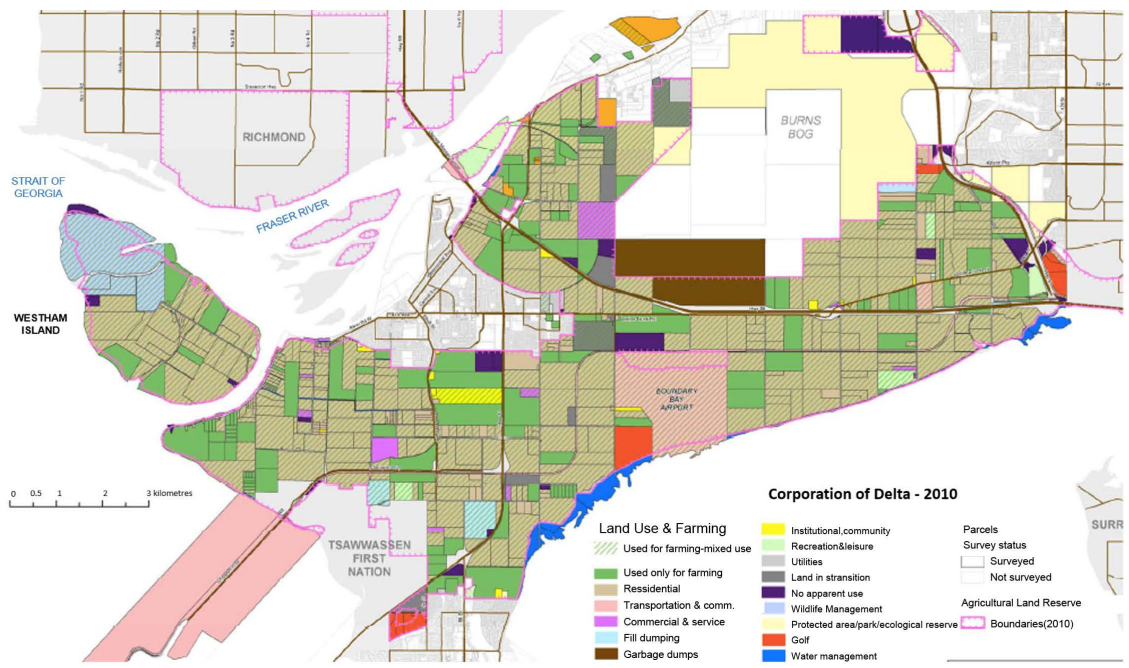

Figure 1. Land use map of Delta, BC (adapted from [14]).

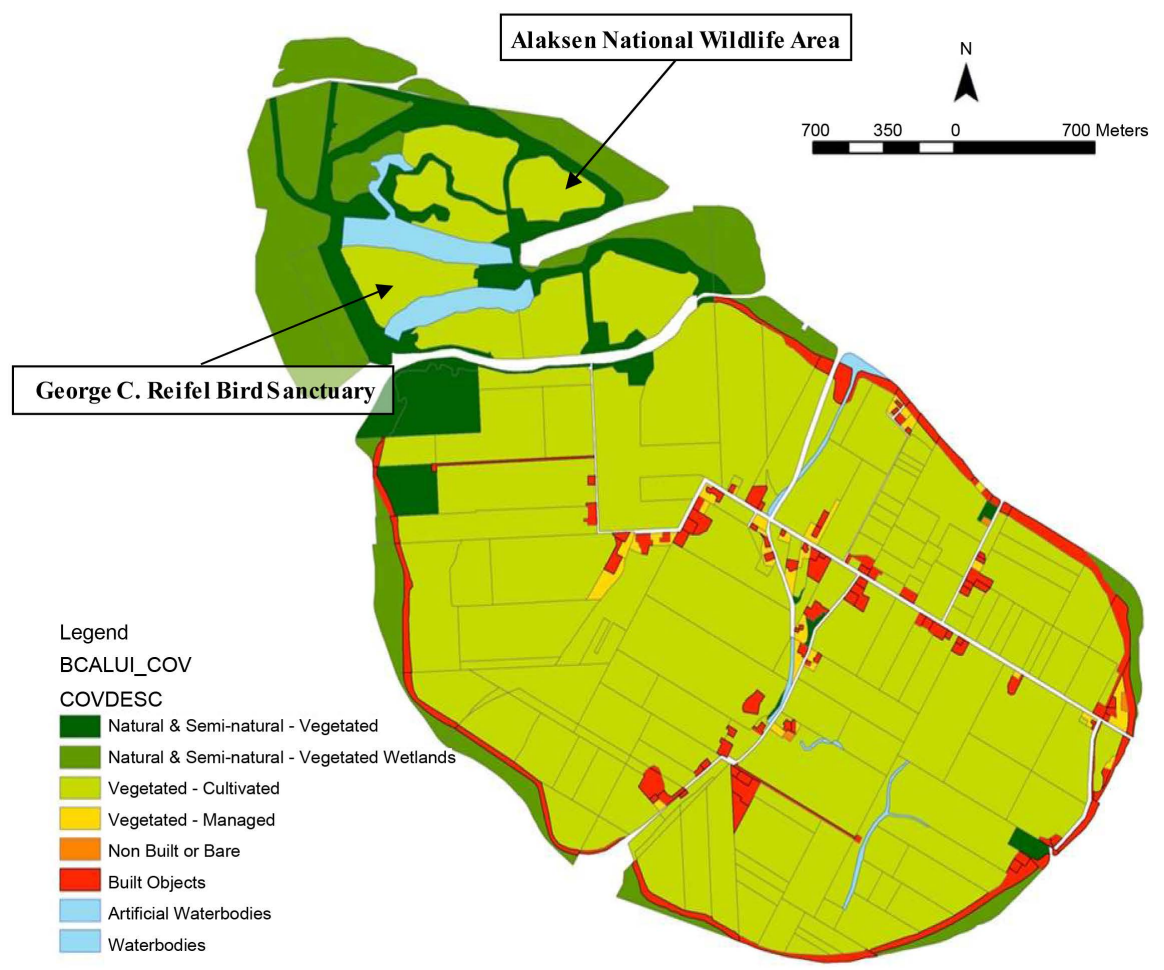

Figure 2. Land use map of Westham Island (with permission from [16]).

eco-and agro-tourism.

By adapting the spatial analysis outlined in [20] and the ecosystem services model InVEST [21], a comprehensive framework was established to evaluate the potential ecosystem services provided by integrating wildlife habitat within agricultural ecosystems. This framework was used to assess and evaluate ecological goods and services of agricultural lands on Westham Island.

The assessment was done within the scope of the DF \& WT's agricultural land stewardship programs. Two of the major programs that focus on wildlife habitat and soil quality are: 1) the Grassland Set-aside Stewardship Program and 2) the 
Winter Cover Crop Stewardship Program.

\subsubsection{Grassland Set-Aside Stewardship Program}

Starting in 1990s, this program has fostered agreements with co-operators (farmers) for a period of 1 - 4 years to encourage them to plant a locally adapted mix of grasses and legumes on harvested fields to restore soil structure and build soil fertility [22]. The stated objectives are to obtain sustainability benefits for both soil quality and wildlife habitat by the establishment of grasses and legumes to improve soil organic matter and soil structure, and to provide a suitable vegetative cover for breeding, roosting and nesting wildlife. In addition, this program assists farmers in transitioning to organic production should they so elect [14].

\subsubsection{Winter Cover Crop Stewardship Program}

This initiative was introduced in 1990 and helps to share the economic cost of establishing a vegetative cover on vegetable fields before the winter season, in order to protect the soil from erosion, improve soil fertility, and provide feeding habitat for herbivorous waterfowl and shorebirds [14] [23].

To address any conflicts related to agricultural land management and wildlife habitat, DF\&WT consults and facilitates discussions with farming and conservation stakeholders. Through research and evaluation of DF\&WT programs, the organization offers solutions to challenges to both agricultural production and wildlife habitat conservation.

Summer crop survey maps supplied by DF\&WT from 2005 (Figure 3) and 2015 (Figure 4) provided information on the change of crop areas and locations under vegetative cover over the last decade. These maps were developed through a windshield survey and thus represent a snapshot in time, and thus there may be some uncertainty with the estimates. However, the data provide a useful indicator of the overall trends in land use change on Westham Island.

\section{Results and Discussion}

\subsection{Food Production}

The changes in crop cover on Westham Island were calculated using Geographic Information Systems (GIS) analysis [24] and are shown in Figure 3 and Figure 4. The calculated areas among the various classes are given in Table 1.

There has been a small net change of classified land area within the last decade, amounting to a slight decrease of 2.5 ha. The category of Unknown Crops identified in 2005 is assumed to be accounted for within the other categories in 2015, and not lost to non-agricultural development. Aside from Unknown Crops, the largest change is in the area devoted to Vegetables, with a decrease of 42.6 ha. There was a relative increase in Other Land and Wild Land categories.

As crop rotation is considered to promote soil fertility and pest control, farmers are encouraged to practice crop rotation by the BC Ministry of Agriculture and Lands [11]. Thus, the crops grown on each farm typically rotate each year. Farmers may be restricted in the kind of crop by quotas for some agricultural commodities. 


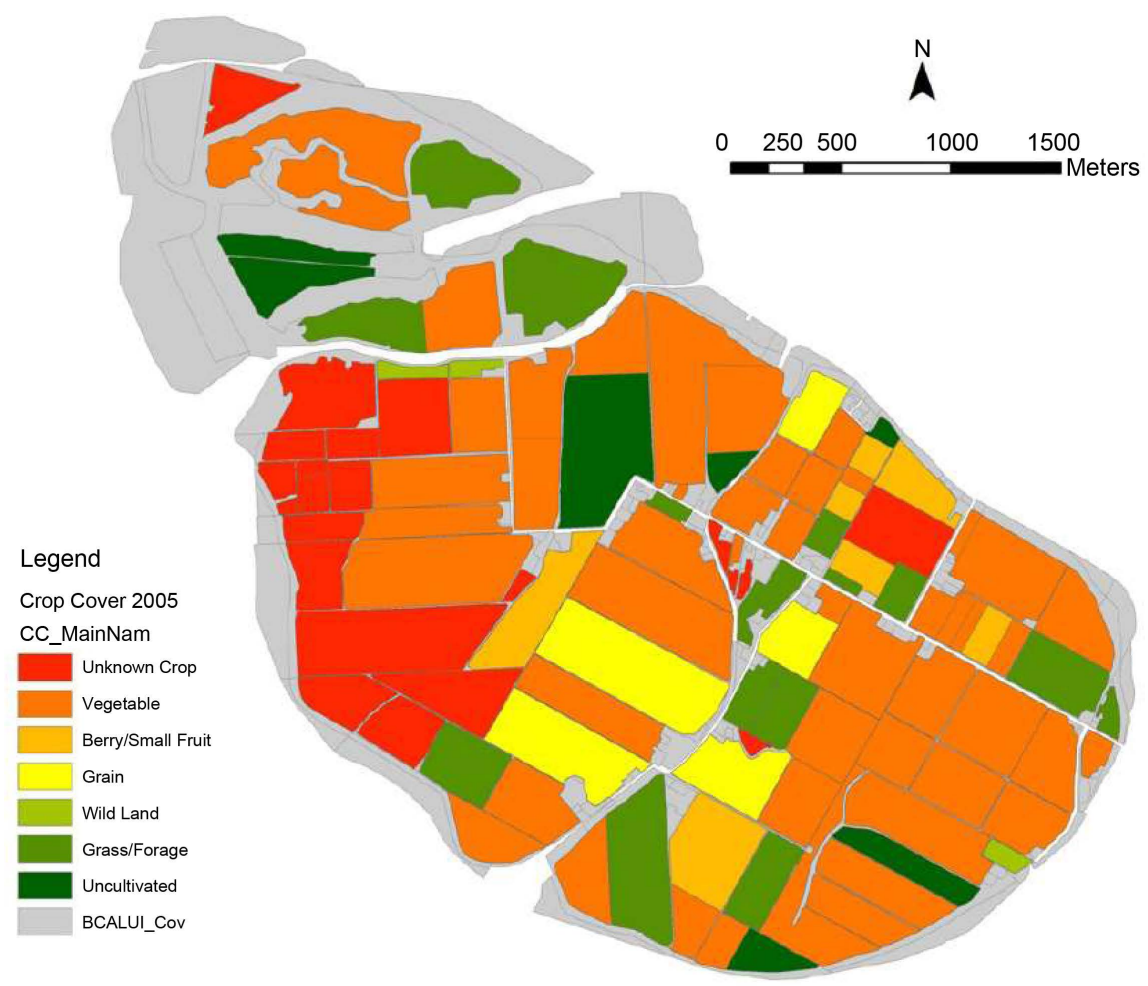

Figure 3. Crop cover on Westham Island in 2005 (with permission from Delta Farmland \& Wildlife Trust).

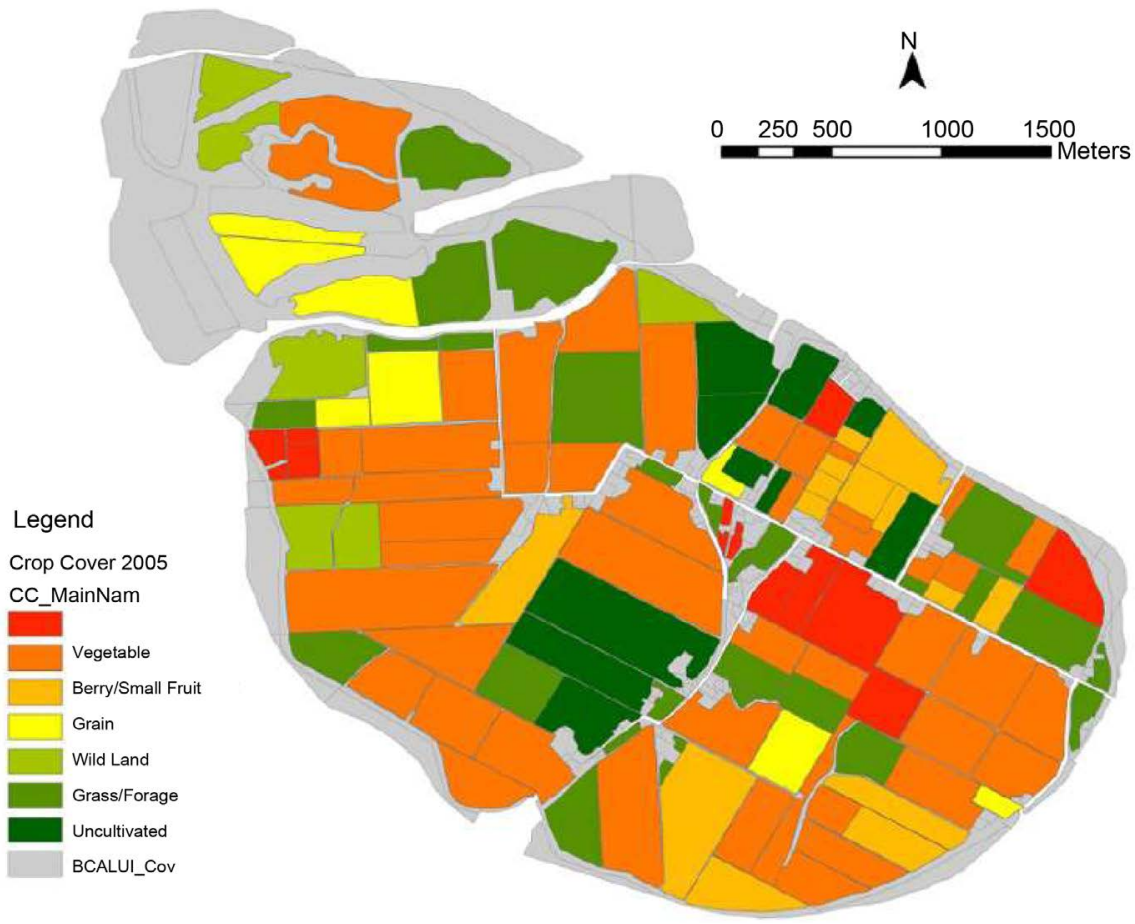

Figure 4. Crop cover on Westham Island in 2015 (with permission from Delta Farmland \& Wildlife Trust).

From the spatial analysis detailed in Figure 3 and Figure 4, a change matrix of land cover area between 2005 and 2015 was generated by GIS analysis. It is 
Table 1. Changes in cropped and wild land areas between 2005 and 2015 on Westham Island in hectares.

\begin{tabular}{cccc}
\hline Crop Cover & $2005(\mathrm{ha})$ & $2015(\mathrm{ha})$ & Changes in Area (ha) \\
\hline Other Land & 10.7 & 47.4 & 36.7 \\
Wild Land & 4.90 & 41.5 & 36.5 \\
Grass/Forage & 99.0 & 131 & 32.4 \\
Uncultivated & 51.1 & 75.1 & 23.9 \\
Berry/Small Fruit & 42.8 & 74.3 & 31.6 \\
Vegetables & 400 & 357 & -42.6 \\
Grain & 62.3 & 47.1 & -15.2 \\
Unknown Crops & 106 & 0.0 & -106 \\
Total/Net & 777 & 773 & -2.5 \\
\hline
\end{tabular}

important to note that the results are a snapshot of the land cover at the time of the survey, and may not represent the land cover throughout the year, as crop-free land may simply be in the process of replanting. However, the numbers presented in Table 2 indicate the area (in hectares) that has changed from 2005 to 2015. The conclusion cannot be considered quantitative since there were differences in identifying the cover types (e.g., a field may be identified as Wild Land due to the Grassland Set-Aside Stewardship Program, and not necessarily undeveloped land). Uncultivated Land may vary depending on the survey period.

Changes have taken place in Uncultivated Land between 2005 and 2015, which have converted to either Grass/Forage (16 ha), Grain (13 ha), or Berry/Small fruit (11 ha). With these conversions, the wildlife habitat value appears to have shifted. Meanwhile, $96 \%$ (72 out of 75 ha) of 2015 Uncultivated Land was transferred from other crops, mainly from Grain fields (36 ha) and Vegetable fields ( $29 \mathrm{ha}$ ). It should be noted that with the nature of the windshield survey, Uncultivated Land does not necessarily mean "barren" land; it may not have been planted for the season at the time of the survey.

The DF\&WT Winter Cover Crop Stewardship Program has been incorporated into many farmers' rotations on Westham Island. Through this program, farmers plant cereal grasses, clover, or annual forage grasses as a cover crop. Cover crops can be under-seeded into growing crops (e.g., cereal grains and silage corn) or planted after cash crops (e.g., beans, peas, and potatoes) have been harvested [15]. The summary statistics for cover cropping on Westham Island are presented in Table 3 and the locations are shown in Figure 5. When comparing winter cover crop program enrollment in the years 1995, 2005 and 2015, an increase in the area planted was evident ( 28\%). In 2005 there were more fields participating in the cover crop program than in 1995 with fewer hectares per field on average, leading to a slight decrease in total area. By 2015, the number of participating fields increased by another third. Such an increase in both the spatial extent and potential diversity of cover crops may be more beneficial 


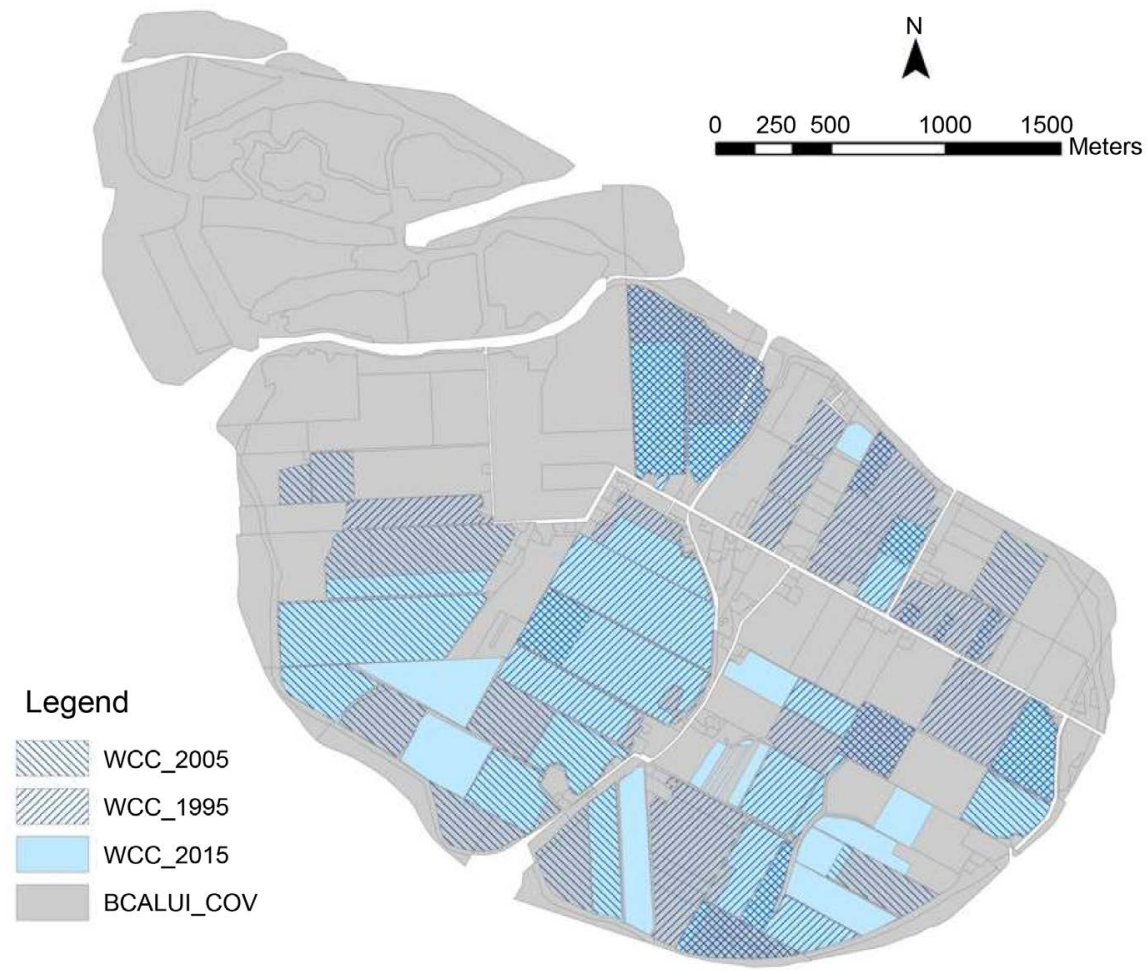

Figure 5. Delta Farmland and Wildlife Trust Winter Cover Crops (WCC) Program participant field locations in 1995, 2005 and 2015.

Table 2. Matrix of change in land cover area (in hectares) between 2005 and 2015 on Westham Island, Delta, BC. The numbers indicate how much area has shifted from the category above it, in 2005, to the category on the left-hand column, in 2015.

\begin{tabular}{|c|c|c|c|c|c|c|c|c|c|}
\hline $\begin{array}{l}2005 \\
2015\end{array}$ & Vegetable & ass/Forage & Grain & $\begin{array}{c}\text { Berry/Small } \\
\text { Fruit }\end{array}$ & $\begin{array}{l}1 \text { Wild } \\
\text { Land }\end{array}$ & Uncultivated & $\begin{array}{l}\text { Unknown } \\
\text { Crops }\end{array}$ & $\begin{array}{l}\text { Other } \\
\text { Land }\end{array}$ & Sum \\
\hline Vegetable & 250 & 38 & 9.6 & 4.1 & 0 & 6.6 & 49 & 1.2 & 360 \\
\hline Grass/Forage & 41 & 45 & 8 & 2.3 & 3.3 & 16 & 12 & 3.8 & 130 \\
\hline Grain & 9.9 & 8.9 & 0 & 0 & 1.7 & 13 & 13 & 0 & 47 \\
\hline $\begin{array}{c}\text { Berry/Small } \\
\text { Fruit }\end{array}$ & 18 & 2.5 & 0 & 34 & 0 & 11 & 0 & 8 & 74 \\
\hline Wild Land & 17 & 0 & 0 & 0 & 0 & 0 & 24 & 0 & 42 \\
\hline Uncultivated & 29 & 3.3 & 36 & 1.5 & 0 & 2.9 & 0 & 2.5 & 75 \\
\hline Other Land & 35 & 1.9 & 8.6 & 0.6 & 0 & 0.5 & 7.8 & 0 & 55 \\
\hline Sum & 400 & 100 & 62 & 43 & 5 & 50 & 106 & 16 & 783 \\
\hline
\end{tabular}

for both increasing the rate of soil fertility recovery, and providing more diverse habitats for wildlife [25]. Thus, the enhancement of provisioning services can improve agricultural production.

\subsection{Wildlife Habitat}

As mentioned, Westham Island is located on the Pacific Flyway, in which the

George C. Reifel Migratory Bird Sanctuary has been identified as a world-class 
Table 3. Areas enrolled in Delta Farmland and Wildlife Trust Winter Cover Crop Stewardship Program on Westham Island.

\begin{tabular}{cccc}
\hline & 1995 & 2005 & 2015 \\
\hline Number of Fields & 16 & 26 & 35 \\
Total Area (ha) & 242 & 209 & 292 \\
Area per field (ha) & 15 & 8.0 & 8.4 \\
\hline
\end{tabular}

migratory stopover for waterfowl to nest, breed and feed; it supports a large amount of wintering concentrations of migratory birds in Canada [26]. The Seasonal Bird Checklist has recorded the birds in the Sanctuary since 1963, when it entered into a partnership with the BC Wildlife Watch Program [27]. The sanctuary is reported to be the home of over 195 regularly occurring species and an additional 95 casual and accidental species visitors [27].

The value of wildlife habitat as an integrated ecosystem services provider by different land use and land cover types was presented in [7]; the authors compared breeding and feeding values of land cover types used in a wildlife habitat capacity analysis for 588 species of birds, mammals, reptiles, and amphibians on the national scale in Canada. The value of a particular land cover type was based on the number of species it supported and its habitat value to them (that is, whether it was primary, secondary, or tertiary).

As an attempt to assess how [7]'s land use value system might apply to the Westham Island example, indicator feeding values were assigned to the land cover data presented in Figure 3, Figure 4 and Table 1. Figure 6 illustrates the change in land cover categories on Westham Island between 2005 and 2015 and how the resulting habitat land value indicators have changed. The intensity of the colour reflects the relative wildlife habitat value provided by each crop type; as the colour changes to red, there is a relative decrease in wildlife habitat value (Figure 6). Generally, the wildlife habitat value was higher in 2015 compared with 2005, especially for Wild Land and with an increase of 37 ha.

In [7]'s ranking system, cultivated lands were considered to be of comparatively low value for wildlife, especially in terms of breeding habitat using a national broad scale. However, although cultivated land may in certain circumstances be less suitable than many wild lands, the provisions, such as a food source for migrating waterfowl and protective cover for many prey species, can support a wide variety of species and provide important habitat sanctuaries, particularly in areas adjacent to densely developed urban centers [28]. Therefore, national scale assessments may not be appropriate to the local municipal level as we see important landscape variability at finer scales. Because [7]'s classification considered a much wider range of wildlife species and landscape types, it is not directly transferable to the Westham Island case study; however, it is a useful evaluation and communication tool, and further investigation into how it may be adapted to Delta is recommended. As an example, it could serve to adjust the value associated with cultivated lands, which are comparatively large in this area 


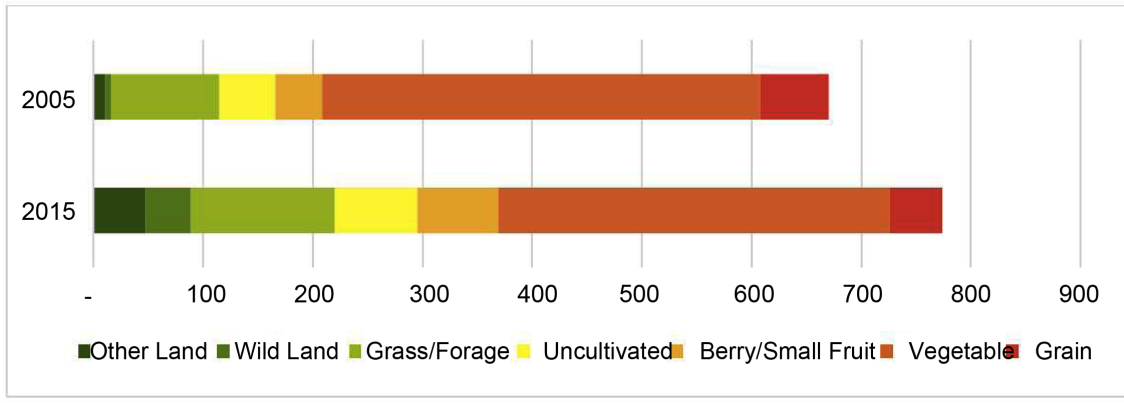

Figure 6. Changes in cropped and wild land cover area (ha) between 2005 and 2015 on Westham Island with associated wildlife habitat value indicator on $\mathrm{x}$-axis. Orange/red colours indicate decreased habitat value (based on methodology from [7]).

and with smaller areas of wild lands.

A comprehensive study of bird counts was conducted by [29] in the Lower Fraser River from Annacis Island to Westham Island (Table 4). Two seasonal peaks in bird abundance were documented, in February to March $(15.5 \%$ and 11.3\%) and September to November (peak at October 12.8\%). Gulls were found to be the largest population among the reported birds that migrated during the winter.

Table 5 shows the population and abundance of the major winter waterfowl surveyed between 1977 and 1987. American wigeon, green-winged teal and mallard had relatively high population levels according to the historical survey, which indicate the importance of the Fraser River Delta and its significance in maintaining wildlife habitat.

With the implementation of the Winter Cover Crop Stewardship Program, there is evidence that cover crops planted in late fall or winter have provided a rich food source and shelter for wildlife, especially for herbivorous waterfowl, such as lesser snow geese, American wigeon, northern pintail, mallard and trumpeter swan [15].

In addition to providing direct food sources and nesting habitats, indirect benefits have been also gained from cover crops. Some species of waterfowl (e.g. Dunlin and Black-bellied plover) have been observed feeding on invertebrates on grazed cover crop fields [15]. Waterfowl can also be lured by cover crops instead of damaging perennial forage [25]. By decreasing winter mortality and improving breeding condition, the waterfowl population has increased [25].

Since grassland set-asides mimic the grasslands that were once abundant on the Lower Fraser River Delta prior to 1890 when land clearing and drainage networks for agriculture began, the set-asides provide ideal surrogate habitat for wildlife [15]. The group of wildlife that benefits the most are small mammals, especially Townsend's vole, that establish under the thick canopy of grass. Meanwhile, predatory birds (e.g. raptors and wading birds) have experienced an increased opportunity to prey on small mammals [15]. Set-asides also provide nesting habitat for grassland birds, as Savannah sparrows and common yellowthroat nests can be found in the set-aside grasslands [15]. 
Table 4. Average number of birds counted by month in boat surveys in the South Arm of the Fraser River from Annacis Island to Westham Island (Dec. 1976-Dec. 1977) [29].

\begin{tabular}{|c|c|c|c|c|c|c|c|c|c|c|c|c|}
\hline \multirow{2}{*}{ Group } & \multicolumn{12}{|c|}{ Month } \\
\hline & Jan & Feb & Mar & Apr & May & Jun & Jul & Aug & Sep & Oct & Nov & Dec \\
\hline Loons & 4 & 4 & 2 & 1 & 0 & 0 & 0 & 0 & 1 & 1 & 2 & 1 \\
\hline Grebs & 171 & 275 & 233 & 326 & 1 & 1 & 1 & $<1$ & 2 & 118 & 288 & 117 \\
\hline Cormorants & 13 & 25 & 92 & 112 & 81 & 4 & 2 & 10 & 15 & 11 & 22 & 26 \\
\hline $\begin{array}{l}\text { Canada } \\
\text { Goose }\end{array}$ & 17 & 81 & 23 & 103 & 73 & 43 & 60 & 135 & 151 & 72 & 8 & 22 \\
\hline Dabblers & 1.648 & 7.139 & 5.397 & 3.257 & 449 & 189 & 172 & 728 & 2.420 & 703 & 393 & 390 \\
\hline Divers & 603 & 633 & 676 & 373 & 90 & 2 & $<1$ & $<1$ & 4 & 16 & 193 & 233 \\
\hline Mergansers & 153 & 120 & 206 & 203 & 34 & 4 & 7 & 1 & 17 & 19 & 30 & 58 \\
\hline Raptors & 22 & 19 & 11 & 7 & 6 & 3 & 6 & 5 & 11 & 13 & 21 & 27 \\
\hline Herons & 2 & 37 & 31 & 38 & 44 & 31 & 38 & 48 & 49 & 44 & 38 & 32 \\
\hline Coots & 82 & 80 & 67 & 91 & 6 & $<1$ & 0 & $<1$ & 12 & 26 & 26 & 20 \\
\hline Shorebirds & 940 & 2.014 & 74 & 536 & 155 & 40 & 298 & 229 & 270 & 544 & 1.069 & 459 \\
\hline Gulls & 7.307 & 11.674 & 9.348 & 7.134 & 10.159 & 984 & 1.372 & 4.146 & 13.328 & 16.635 & 14.004 & 6.436 \\
\hline Passerines & 184 & 334 & 238 & 306 & 479 & 641 & 630 & 523 & 260 & 189 & 221 & 257 \\
\hline Others & 5 & 5 & 4 & 568 & 41 & 72 & 115 & 103 & 190 & 199 & 59 & 5 \\
\hline Total & 11.176 & 22.440 & 16.402 & 13.055 & 11.618 & 2.014 & 2.701 & 5.928 & 16.730 & 18.590 & 16.374 & 8.083 \\
\hline Percentage & $7.70 \%$ & $15.50 \%$ & $11.30 \%$ & $9.00 \%$ & $8.00 \%$ & $1.40 \%$ & $1.90 \%$ & $4.10 \%$ & $11.50 \%$ & 6 12.80\% & $11.30 \%$ & $5.60 \%$ \\
\hline
\end{tabular}

Table 5. Population estimates of maximum number of waterfowl by species during winter in the Fraser River Delta [13].

\begin{tabular}{cccc}
\hline Species & Population & Relative & Reference \\
\cline { 2 - 3 } & estimates & Abundance (\%) & {$[30]$} \\
Trumpeter Swan & 125 & $<0.1$ & {$[30]$} \\
Tundra Swan & 125 & $<0.1$ & {$[13]$} \\
Greater Goose & 25 & $<0.1$ & {$[30]$} \\
Snow Goose & 40,000 & 13 & {$[30]$} \\
Brant & 4500 & 1.5 & {$[13]$} \\
Canada Goose & 100 & $<0.1$ & {$[31]$} \\
Green-winged Teal & 50,000 & 16.3 & {$[31]$} \\
Mallard & 50,000 & 16.3 & {$[31]$} \\
Northern Pintail & 35,000 & 11.4 & {$[32]$} \\
Northern Shoveler & 100 & $<0.1$ & {$[31]$} \\
American Wigeon & 62,000 & 20.2 & {$[13]$} \\
Canvasback & 1600 & 0.5 & {$[31]$} \\
Scaup & 30,000 & 9.8 & {$[31]$} \\
Oldsquaw & 1200 & 0.4 & {$[33]$} \\
Scoters & 14,000 & 4.6 & {$[33]$} \\
Goldeneye & 1600 & 0.5 & {$[33]$} \\
Bufflehead & 5900 & 1.9 & {$[33]$} \\
Merganser & 1000 & 0.2 & \\
Ruddy Duck & 9200 & 3 & \\
\hline
\end{tabular}




\subsection{Ancillary Ecosystem Services}

\subsubsection{Pollination}

There is concern that conventional agriculture has negative impacts on wild pollinator populations and biodiversity, due to habitat fragmentation and application of agrichemicals, for example [34]. To address these concerns, collaborative programs, like the DF\&WT, have implemented measures to improve pollinator provisioning. Grass margins can provide spatial breaks between agricultural fields, and when grass margins contain clover or other legumes, they can provide a food source for pollinating insects [22]. Winter cover crops provide farmers with an opportunity to establish vegetative cover on fields before winter. If the cover crops include early-flowering vetches, these may be beneficial as they provide forage for pollinators early in the season before many other crops have bloomed [35]. Early spring forages are beneficial for domestic European honeybees, as well as for the many wild bees that live in the area [35].

In addition, grassland set-asides and crop rotations provide habitat for a diversity of pollinators, like bumblebees [22]. This diversity further improves the ecosystem services of pollination and can actually improve agricultural productivity [36].

\subsubsection{Soil Quality}

A common characteristic of the soils on Westham Island is their poorly drained conditions with relatively high water holding capacity and high organic matter content in the cultivated surface layer [14]. With good drainage management, they have the potential to be improved to become more suitable for a wide range of agricultural crops, such as annual legumes, blueberries, root vegetables, and strawberries [37].

Grassland set-asides enhance soil structure, which is very important to sustain agricultural production [38]. Providing the $1-4$ year fallow period can affect the soil structure, water retention, drainage, soil microbial activity, macro-invertebrates, nutrient storage and nutrient uptake by crops [15].

Winter cover crops provide the ecosystem services of preventing rain-induced soil erosion, increasing soil organic matter, improving soil structure, increasing the water holding capacity, increasing the infiltration of water, fixing nitrogen and offsetting the need for commercial inorganic fertilizers. While directly improving soil health, cover crops also increase yields [15].

Table 6 provides a summary of the key ecosystem services that the DF\&WT programs contribute to enhance soil quality. All of these management practices improve agricultural production in the long term, although there may be a lost opportunity cost or loss of revenue during the set-aside period compared to continuous planting and harvesting.

\subsubsection{Eco- and Agro-Tourism}

Improvements in habitat capacity of farmlands through the DF\&WT Winter Cover Crop and Grassland Set-Aside Stewardship Programs has aided in maintaining the biodiversity of wildlife on Westham Island. This, in turn, may pro- 
vide an indirect eco-tourism benefit to the area, as more tourists visit the Island to view wildlife.

Figure 7 identifies the main locations for eco- and agro-tourism on Westham

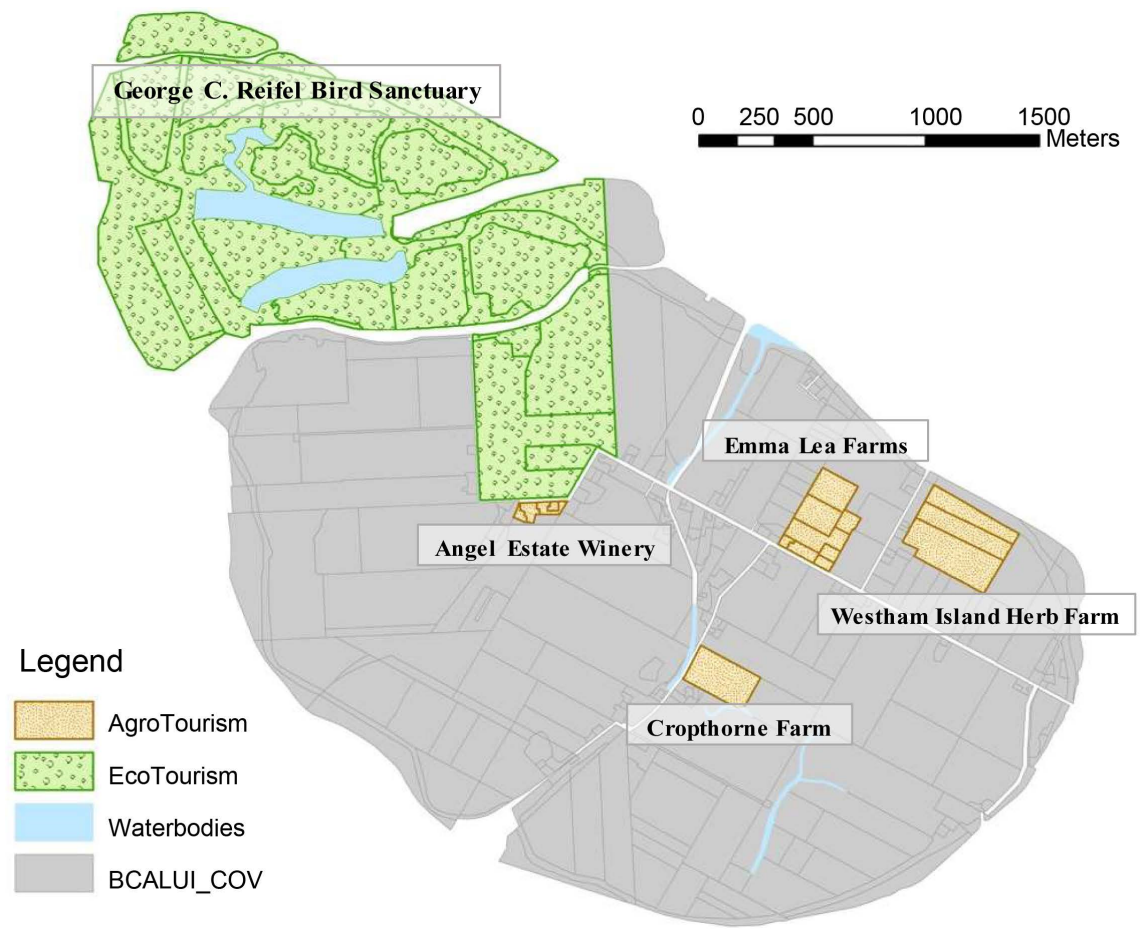

Figure 7. Locations of main eco- and agro-tourism sites on Westham Island, Delta, BC (2015).

Table 6. Ecosystem services provided by the implementation of Delta Farmland \& Wildlife Trust Programs.

\begin{tabular}{|c|c|c|}
\hline Program & Ecosystem Services & Processes/Reasons \\
\hline \multirow[t]{5}{*}{$\begin{array}{l}\text { Grassland Set-aside Stewardship } \\
\text { Program }\end{array}$} & Water retention & $\begin{array}{l}\text { Increase in water } \\
\text { holding capacity }\end{array}$ \\
\hline & Drainage & $\begin{array}{l}\text { Increase in soil macropores; the roots } \\
\text { of grasses, especially clover, can bore } \\
\text { channels through compacted soil }\end{array}$ \\
\hline & $\begin{array}{l}\text { Soil microbial activity, } \\
\text { macro invertebrates }\end{array}$ & Increase in aeration \\
\hline & Nutrient retention & Replenish soil organic matter \\
\hline & Nitrogen Fixation & $\begin{array}{l}\text { Plant cover that may decrease use of } \\
\text { fertilizers }\end{array}$ \\
\hline \multirow[t]{4}{*}{$\begin{array}{c}\text { Winter Cover Crop Stewardship } \\
\text { Program }\end{array}$} & $\begin{array}{l}\text { Prevent rain-induced soil } \\
\text { erosion }\end{array}$ & $\begin{array}{l}\text { Increase soil porosity and break up } \\
\text { compaction by the roots }\end{array}$ \\
\hline & Nutrient retention & $\begin{array}{l}\text { Cereal cover crops scavenge nutrients } \\
\text { from leaching along with the heavy } \\
\text { winter rains }\end{array}$ \\
\hline & Nitrogen fixation & $\begin{array}{l}\text { Plant clover cover that may decrease } \\
\text { use of fertilizers }\end{array}$ \\
\hline & $\begin{array}{l}\text { Reduction in chemical } \\
\text { controls }\end{array}$ & $\begin{array}{l}\text { Cover crops can shade weeds and } \\
\text { some release allelopathic compounds } \\
\text { that inhibit weed growth }\end{array}$ \\
\hline
\end{tabular}


Island. The George C. Reifel Migratory Bird Sanctuary consists of nearly 300 hectares of managed wetlands, natural marshes and low dykes at the northern end of the Island and has been reported to host over 70,000 visitors annually [26]. Ranked as one of the top ten bird-watching sites in Canada, the Sanctuary attracts diverse groups of visitors, from children in school programs and families, to birdwatchers and photographers [26].

There are four farms on Westham Island which operate as tourism and recreation centers: Angel Estate Winery, Emma Lea Farms, Westham Island Herb Farm and Cropthorne Farm. Direct agricultural marketing is increasing and farm-related activities have been providing additional economic benefits, as well as diversifying farm operations [39].

\section{Conclusions}

An integrated assessment of the ecosystem goods and services on Westham Island demonstrated that enhanced ecosystem goods and services may be achieved by collaborative ventures focusing on the whole system, rather than solely through an agricultural production lens. Westham Island farmers participating in programs promoted by the DF \& WT that incorporate grassland set-asides and winter cover crops have decreased potential conflict between sustaining wildlife habitat services and agricultural production. The management regimes are complementary and mutually beneficial, as agricultural crop rotations contribute to habitat for wildlife, especially waterfowl, and, soil quality has been maintained, providing benefits to agricultural production in the longer term.

The increase in diversity of cover crops and flower-rich plants has improved the potential for insect pollination, and this integration of agricultural production and pollination services has had a positive effect on wildlife habitat by providing additional food sources. These ecosystem services may have had an indirect impact on cultural services, such as eco- and agro-tourism, educational and aesthetic services. The implementation of the Grassland Set-Aside and Winter Cover Crop Stewardship Programs has also improved soil quality for maintaining and improving agricultural production as initiated by the DF\&WT.

In order to provide for further development and assessment of ecosystem goods and services, the application of the "willingness-to-pay" to address some of the more qualitative services should be considered. The geographical setting of the study area encompasses important groundwater resources, intensive agriculture, and is located on an international bird flyway in a peri-urban environment; these qualities provide the opportunity to extend, through appropriate data collection, the assessment of additional provisions of ecosystem goods and services that include water management strategies to minimize increased salinity from irrigation, flooding and contamination of local water resources.

By the improvement in soil quality it is likely that carbon dioxide sequestration will also increase. The integrated collaborative framework on Westham Island could address concerns regarding carbon markets and offset programs, and how carbon sequestration and storage might be adapted to different manage- 
ment regimes [40] [41]. In addition, there is an opportunity to extend [7]'s model for the linkages between local wildlife species and different agricultural landscape covers to better reflect the synergies between wildlife habitat values on Westham Island and the Fraser River delta.

\section{Acknowledgements}

Sincere thanks are expressed to the Delta Farmland and Wildlife Trust, Ducks Unlimited Canada, B.C. Ministry of Agriculture, Agriculture and Agri-Food Canada, and the Canadian Wildlife Service - Pacific and Yukon Region, for providing information for the study. A special note of thanks and gratitude to Christine Terpsma, former Program Coordinator of the Delta Farmland and Wildlife Trust, Delta, British Columbia.

This research did not receive any specific grant from funding agencies in the public, commercial, or not-for-profit sectors.

\section{References}

[1] United Nations Environment Programme (UNEP) (2005) One Planet, Many People: Atlas of Our Changing Environment. United Nations, New York.

[2] Costanza, R., d'Arge, R., de Groot, R., Farber, S., Grasso, M., Hannon, B., Naeem, S., Limburg, K., Paruelo, J., O’Neill, R.V., Raskin, R., Sutton, P. and van den Belt, M. (1997) The Value of the World's Ecosystem Services and Natural Capital. Nature, 387, 253-260. https://doi.org/10.1038/387253a0

[3] Daily, G.C., Alexander, S., Ehrlich, P.R., Goulder, L., Lubchenco, J., Matson, P.A., Mooney, H.A., Postel, Schneider, S.H., Tilman, D. and Woodwell, G.M. (1997) Ecosystem Services: Benefits Supplied to Human Societies by Natural Ecosystems. Ecology, 2, 18.

[4] Heywood, V.H. (1995) Global Biodiversity Assessment. United Nations Environment Programme. Cambridge University Press, Cambridge.

[5] Krebs, J.R., Wilson, J.D., Bradbury, R.B. and Siriwardena, G.M. (1999) The Second Silent Spring? Nature, 400, 611-612. https://doi.org/10.1038/23127

[6] Tilman, D., Cassman, K.G., Matson, P.A., Naylor, R. and Polasky, S. (2002) Agricultural Sustainability and Intensive Production Practices. Nature, 418, 671-677. https://doi.org/10.1038/nature01014

[7] Javorek, S.K. and Grant, M.C. (2011) Trends in Wildlife Habitat Capacity on Agricultural Land in Canada, 1986-2006. Canadian Biodiversity: Ecosystem Status and Trends 2010, Technical Thematic Report No. 14, Canadian Councils of Resource Ministers, Ottawa.

http://www.biodivcanada.ca/B6A77C14-9B4F-48EC-BB73-8154756129E9/4671No.1 4_Wildlife\%20Habitat\%20Capacity_Jun2012_E.pdf

[8] Polasky, S., Nelson, E., Camm, J., Csuti, B., Fackler, P., Lonsdorf, E., Montgomery, C., White, D., Arthur, J. and Garber-Yonts, B. (2008) Where to Put Things? Spatial Land Management to Sustain Biodiversity and Economic Returns. Biological Conservation, 141, 1505-1524.

[9] Power, A.G. (2010) Ecosystem Services and Agriculture: Tradeoffs and Synergies. Philosophical Transactions of the Royal Society B: Biological Sciences, 365, 29592971. https://doi.org/10.1098/rstb.2010.0143

[10] Olewiler, N. (2004) The Value of Natural Capital in Settled Areas of Canada. Ducks 
Unlimited Canada and the Nature Conservancy of Canada. http://www.cmnbc.ca/sites/default/files/natural\%2520capital_0.pdf

[11] BC Ministry of Agriculture and Lands (2007) Public Amenity Benefits and Ecological Services Provided by Farmland to Local Communities in the Fraser Valley. Strengthening Farming Report, 800, 100-101.

[12] Agricultural Land Commission (ALC) (2014) Agricultural Land Reserve (ALR) History. http://www.alc.gov.bc.ca/alc/content/alr-maps/alr-history

[13] Butler, R.W. and Campbell, R.W. (1987) The Birds of the Fraser River Delta: Populations, Ecology and International Significance. Occasional Paper No. 65, Canadian Wildlife Service, Delta.

[14] Zbeetnoff Agro-Environmental Consulting and Quadra Planning Consultants (2011) Delta Agricultural Plan, Phase 1: Delta Agriculture Profile. The Corporation of Delta.

http://www.delta.ca/docs/default-source/community-planning-and-development/ag ricultural-plan/delta-agricultural-profile.pdf?sfvrsn $=0$

[15] Delta Farmland \& Wildlife Trust (DF\&WT) (2014) Annual Report: Conserving Farmland and Wildlife through Co-Operative Land Stewardship.

http://www.deltafarmland.ca/admin/userfiles/files/DF\&WT\%20Annual\%20Report \%202014(1).pdf

[16] BC Ministry of Agriculture (2010) Agricultural Land Use Inventories. Agricultural Land and Environment Program, Province of British Columbia.

http://www2.gov.bc.ca/gov/content/industry/agriculture-seafood/agricultural-landand-environment/strengthening-farming/planning-for-agriculture/agricultural-lan d-use-inventories

[17] Environment Canada (2017) Environment Canada, National Climate Data and Information Archive. Downsview, Ontario. http://www.climate.weatheroffice.gc.ca

[18] Millennium Ecosystem Assessment (2005) Ecosystems and Human Well-Being: Synthesis. Island Press, Washington DC.

[19] De Groot, R.S., Alkemade, R., Braat, L., Hein, L. and Willemen, L. (2010) Challenges in Integrating the Concept of Ecosystem Services and Values in Landscape Planning, Management and Decision Making. Ecological Complexity, 7, 260-272.

[20] Andrew, M.E., Wulder, M.A., Nelson, T.A. and Coops, N.C. (2015) Spatial Data, Analysis Approaches, and Information Needs for Spatial Ecosystem Service Assessments: A Review. GIscience \& Remote Sensing, 52, 344-373. https://doi.org/10.1080/15481603.2015.1033809

[21] Natural Capital Project (2016) In VEST Integrated Valuation of Ecosystem Services and Tradeoffs. http://www.naturalcapitalproject.org/invest/

[22] Delta Farmland and Wildlife Trust (DF\&WT) (2010) Grassland Set-Aside Stewardship Program.

http://www.deltafarmland.ca/subpage/our-programs/grassland-set-aside-stewardshi p-program

[23] Delta Farmland and Wildlife Trust (DF\&WT) (2011) Winter Cover Crop Stewardship Program.

http://www.deltafarmland.ca/subpage/our-programs/winter-cover-crop-stewardshi p-program/

[24] ESRI (2016) ArcGIS Platform, v. 10. http://www.esri.com/arcgis/about-arcgis

[25] Bradbeer, D., Lansdorp, O., Travers, M., Jack, K. and Halpin, L. (2012) Winter Cover Crops on the Fraser River Delta: 20 Years of Greenfields. Report Prepared for the Delta Farmland \& Wildlife Trust. 
http://www.deltafarmland.ca/admin/userfiles/file/Winter\%20Cover\%20Crops\%20o n\%20the\%20Fraser\%20River\%20Delta\%2020\%20Years\%20of\%20Greenfields.pdf

[26] BC Waterfowl Society (2013a) About the Sanctuary. George C. Reifel Migratory Bird Sanctuary. http://www.reifelbirdsanctuary.com/about.html

[27] BC Waterfowl Society (2013b) Seasonal Bird Checklist. George C. Reifel Migratory Bird Sanctuary. http://www.reifelbirdsanctuary.com/birds.html

[28] Bossenmaier, E.F. and Marshall, W.H. (1958) Field-Feeding by Waterfowl in Southwestern Manitoba. Wildlife Monographs, 1, 1-32.

[29] Blood, D.A. (1978) Migratory Bird Use of South Arm of Fraser River December 1976 through November 1977. Canadian Wildlife Service Report.

[30] McKelvey, R.W., Smith, D.W., Smith, G.E.J. and Keller, K.A. (1985) The Interaction of Birds and Air Traffic at Boundary Bay Airport. Unpublished Report, Canadian Wildlife Service, Delta.

[31] Vermeer, K. and Levings, C.D. (1977) Populations, Biomass and Food Habits of Ducks on the Fraser Delta Intertidal Area, British Columbia. Wildfowl, 28, 12.

[32] Campbell, R.W. (1972) The Green Heron in British Columbia. Syesis, 5, 235-247.

[33] Savard, J.P.L. (1985) Fall and Winter Inventories of Ducks on the Fraser River Delta and Boundary Bay, 1977-1978. Unpublished Report, Canadian Wildlife Service, Delta.

[34] Potts, S.G., Biesmeijer, J.C., Kremen, C., Neumann, P., Schweiger, O. and Kunin, W.E. (2010) Global Pollinator Declines: Trends, Impacts and Drivers. Trends in Ecology and Evolution, 25, 345-353.

[35] Koebel, A., Furey, G. and Riseman, A. (2014) Flowering and Regrowth of Hairy Vetch Cultivars Used for Pollinator Forage and Reduced Tillage.

[36] Wratten, S.D., Gillespie, M., Decourtye, A., Mader, E. and Desneux, N. (2012) Pollinator Habitat Enhancement: Benefits to Other Ecosystem Services. Agriculture, Ecosystems \& Environment, 159, 112-122.

[37] Kenk, E. and Cotic, I. (1983) Land Capability Classification for Agriculture in British Columbia. Manual 1, Surveys and Resource Mapping Branch, Ministry of Environment and Soils, Ministry of Agriculture and Food, Kelowna.

http://www.alc.gov.bc.ca/assets/alc/assets/library/agricultural-capability/land_capab ility_classification_for_agriculture_in_bc_1983.pdf

[38] Yates, D.E. (2014) Effects of Grassland Set-Asides on Selected Soil Properties in the Fraser River Delta of British Columbia (Thesis). The University of British Columbia. https://open.library.ubc.ca/cIRcle/collections/24/items/1.0167401

[39] BC Ministry of Agriculture (2016) Agri-Tourism Balance Supports Farmers, Celebrates Farming. News Release. https://news.gov.bc.ca/11661

[40] Conte, M., Nelson, E., Carney, K., Fissore, C., Olwero, N., Plantinga, A. and Ricketts, T. (2011) Terrestrial Carbon Sequestration and Storage. In: Daily, G., Kareiva, P. and Ricketts, T., Eds., Natural Capital: Theory and Practice of Mapping Ecosystem Services, Oxford University Press, Oxford, 111-128. https://doi.org/10.1093/acprof:oso/9780199588992.003.0007

[41] Thiel, B., Krzic, M., Gergel, S., Terpsma, C., Black, A., Jassal, R. and Smukler, S. (2016) Soil $\mathrm{CO}_{2}, \mathrm{CH}_{4}$ and $\mathrm{N}_{2} \mathrm{O}$ Emissions from Production Fields with Planted and Remnant Hedgerows in the Fraser River Delta of British Columbia. Agroforestry Systems, 1-18. https://doi.org/10.1007/s10457-016-9990-3 
Submit or recommend next manuscript to SCIRP and we will provide best service for you:

Accepting pre-submission inquiries through Email, Facebook, LinkedIn, Twitter, etc. A wide selection of journals (inclusive of 9 subjects, more than 200 journals)

Providing 24-hour high-quality service

User-friendly online submission system

Fair and swift peer-review system

Efficient typesetting and proofreading procedure

Display of the result of downloads and visits, as well as the number of cited articles Maximum dissemination of your research work

Submit your manuscript at: http://papersubmission.scirp.org/

Or contact as@scirp.org 